\title{
Recycling of construction and demolition waste for producing new construction material (Brazil case-study)
}

\author{
M. Contreras ${ }^{a, *}$, S.R. Teixeira ${ }^{\mathrm{b}}$, M.C. Lucas $^{\mathrm{b}}{ }^{\text {, L.C.N. Lima }}{ }^{\mathrm{b}}$, D.S.L. Cardoso ${ }^{\mathrm{b}}$, G.A.C. da Silva ${ }^{\mathrm{b}}$, \\ G.C. Gregório ${ }^{\mathrm{b}}$, A.E. de Souza ${ }^{\mathrm{b}}$, A. dos Santos ${ }^{\mathrm{c}}$ \\ ${ }^{a}$ Department of Applied Physics, University of Huelva, Campus de Excelencia Internacional del Mar (CEIMAR), 21071 Huelva, Spain \\ ${ }^{\mathrm{b}}$ Universidade Estadual Paulista - UNESP, FCT/DFQB, Presidente Prudente - SP, Brazil \\ ${ }^{\mathrm{C}}$ Universidade do Oeste Paulista - UNOESTE, LABCIVIL, Presidente Prudente - SP, Brazil
}

\section{H I G H L I G H T S}

- Low-cost bricks were manufactured using construction and demolition waste (CDW).

- Lime and cement used as binding agents mixed with CDW and water.

- The bricks present better technological properties than standards.

- The use of this waste reduce the raw materials demands and environmental impacts.

\section{A R T I C L E I N F O}

\section{Article history:}

Received 18 February 2016

Received in revised form 21 June 2016

Accepted 15 July 2016

Available online 21 July 2016

\section{Keywords:}

Civil engineering

Recycling

Brick

CDW

Lime

Cement

\begin{abstract}
A B S T R A C T
Construction and demolition waste corresponds to $50 \%$ of all urban solid waste, usually it is dumped in improper places. This work reuses this waste as substitute of natural aggregate to produce bricks. Lime and cement were used as binding agents and were pressed using a uniaxial hydraulic press. After 21 days curing were submitted to compression tests, the probes presented an average resistance greater than $4 \mathrm{MPa}$, which is higher than standards. Water absorption, apparent porosity and density were also determined. The results show that it is possible to produce low-cost bricks with excellent physical properties using CDW as aggregate and lime or cement as additive.
\end{abstract}

(C) 2016 Elsevier Ltd. All rights reserved.

\section{Introduction}

Construction demolition waste (CDW) is a worldwide problem. The estimated CDW production in Brazil is higher than $70 \mathrm{Mt} / \mathrm{year}$ (around $500 \mathrm{~kg} /$ year per capita), but this amount is variable and has correlation with the human development index (HDI). CDW represents the largest amount of municipal solid waste (in mass). The illegally dumped waste in urban areas, nearby creeks, roads and other unprepared places has substantial environmental and economical impacts resulting in financial problems for the community and public administration. In the last years, governments have approved new policies about responsibilities, dumping and recycling of waste in general. As a result, the situation in the major

\footnotetext{
* Corresponding author.

E-mail address: manuel.contreras@dfa.uhu.es (M. Contreras).
}

cities is changing with the implantation of recycling plants, but nowadays only a small part of the CDW is recovered.

On the other hand, recycling has another environmental and economic advantages, since it reduces the consumption of natural resources. So, there is a comprehensive array of research on the social and financial cost, production, characterization and recycling of this waste [1-4]. CDW recycling plants have been proved to be economically viable $[5,6]$ as well as having a positive environmental impact $[7,8]$.

However, it is essential to absorb the output from these plants by the market. In other words, there is a strong need to diversify the industrial applications of this waste. CDW materials have been evaluated and successfully implemented in recent years in several countries [9,10], and generally, it is used as raw mineral materials in paving projects [11-14], footpaths [15] and pipe-bedding [16]. Some author have focused in recycling CDW for concrete production 
[17-20]. Moreover, others researchers have developed new application as concrete brick [21-22] and concrete block [21,23-25]. Mymrin et al. (2015) have developed a new construction material from CDW and waste from lime production industry with better mechanical properties that Brazilian standards establishes [26]. But there is still a great need for new products, processes and markets, to reduce the volume produced and to recycle most of the CDW $[1,3]$.

In general, CDW mineral fraction is very heterogeneous (mortar, ceramics, concrete, rocks, natural gravel, masonry, sand, soil, etc.) and depends on the characteristics of each construction. Besides, the extent of economic development of each region defines the chemical composition of the waste [27]. Consequently, CDW presents a wide range of porosity and particles size (bulk specific gravity variability from 1.7 to $3.0 \mathrm{~kg} / \mathrm{dm}^{3}$ and water absorption variability from 0 to $20.6 \%$ ). Essentially, these minerals are mainly made up of silicates from ceramic and natural rocks and carbonates from cement-based particles. Hydrated cement-based phases also must be present. Phyllosilicate content is more relevant in the size fraction below $0.15 \mathrm{~mm}$ due probably to soil incorporation [1,4]. Although, the CDW fraction below $4.8 \mathrm{~mm}$ obtained in most of the plants is, generally, not used and represents approximately $40 \%$ of the total mass [2]. The present work is focused and proposes an alternative use for this fraction.

In view of the above, the main objective of this work was to evaluate the possibility of producing bricks, using lime or cement as binders, to construct low-cost housing, with construction and demolition waste (CDW) with the fraction below $4.8 \mathrm{~mm}$ as substitute of natural aggregates. As secondary objective was to evaluate, in term of mechanical behaviour, the different composition of CDW (mixture 50:20:30 (TSC1) and other randomly obtained in a recycling plant (TSC2)). The physical and technological properties of probes were determined and compared with Brazilian, European and American standards, looking for commercial applications for this residue.

\section{Materials and methods}

\subsection{Materials ( $C D W$, cement and lime)}

Representative samples of two different types of CDW (Class A) [28] were obtained from two different metropolitan regions of São Paulo State (SP) Brazil, in order to compare the heterogeneity of these samples evaluating the technological properties. Sample 1 (Presidente Prudente County) was collected from the transporting containers disposed at the work sites of construction and demolition. Sample 2 was collected from a CDW Recycling Plant (São José do Rio Preto County). The samples were grounded and sieved through a $4.8 \mathrm{~mm}$ mesh sieve and used only fraction $<4.8 \mathrm{~mm}$.

According to previous works [29,30], CDW in Presidente Prudente is mainly composed by ceramic (50\%), concrete (20\%) and mortar (30\%). CDW shows a vast array of elements in its composition, majorly containing $\mathrm{SiO}_{2}$ (40-70 wt.\%), $\mathrm{CaO}$ (10-25 wt.\%), $\mathrm{Al}_{2} \mathrm{O}_{3}$ (5-20 wt.\%), $\mathrm{Fe}_{2} \mathrm{O}_{3}$ (0.5-8 wt.\%) and $\mathrm{K}_{2} \mathrm{O}$ (1-4 wt.\%). Similar characteristics was also reported in other studies [31-33].

Portland cement (type I) and hydrated lime (HL III) were used as binder. Portland cement type I is composed of clinker and gypsum [34]. Portland cement contains mainly $\mathrm{CaO}, \mathrm{SiO}_{2}, \mathrm{Al}_{2} \mathrm{O}_{3}$ and $\mathrm{Fe}_{2} \mathrm{O}_{3}$ (60-67, 17-25, 3-8 and 0.5-6 wt.\%, respectively) as stated by the Brazilian standards (NBR) [35] and the U.S. National Bureau of Standards (NBS) [36]. The Hydrated Lime (CH III) is a high quality dolomitic lime, meeting the technical requirements of ABNT 7175 [37]. According to Brazilian building quicklime requirements [38], lime had a $\mathrm{CaO}$ and $\mathrm{MgO}$ content higher than 88-90 wt.\%, and contained appreciable amounts of carbon dioxide (up to 12 wt.\%).

\subsection{Testing samples (TS) preparation}

A total of three series of mixtures were prepared in the laboratory trials as test specimens (TS). Series I and series II mixtures were prepared for producing concrete bricks using CDW from Sample 1 and 2 respectively; series III mixtures were prepared for making lime bricks with CDW Sample 1. The details of these three series of mixes are given in Table 1. The mix notations indicate the different types of mixes (with TSC for concrete bricks and TSL for lime bricks), the notations of CDW aggregates (Sample 1 and 2), and the percentages (by weight) of the additive
Table 1

Composition of the different tests.

\begin{tabular}{llll}
\hline & CDW/additive (wt.\%) & Water (wt.\%) & Nomination \\
\hline CDW $^{\mathrm{a}}$ - cement & $90-10$ & 13 & TSC1-10 \\
& $80-20$ & & TSC1-20 \\
& $70-30$ & & TSC1-30 \\
CDW $^{\mathrm{b}}$ - cement & $90-10$ & 13 & TSC2-10 \\
& $80-20$ & & TSC2-20 \\
& $70-30$ & & TSC2-30 \\
CDW $^{\mathrm{a}}$ - lime & $80-20$ & 12 & TSL1-20 \\
& $75-25$ & & TSL1-25 \\
& $70-30$ & & TSL1-30 \\
& $65-35$ & & TSL1-35 \\
\hline
\end{tabular}

\footnotetext{
a Using classified CDW (50/20/30).

b CDW with randomly composition from a recycling plant.

c wt\% of solid mass.
}

(cement or lime) in the total amount. The materials were mixed manually, moistened and homogenized. The cylindrical TS $(\phi=30 \mathrm{~mm}, \mathrm{~h} \approx 60 \mathrm{~mm})$, were pressed in triplicate, utilizing a uniaxial manual hydraulic press and load of 7 tonf (tons-force)

\subsection{Methods}

The particle size analysis of CDW was performed by a mechanical shaker using sieves Granutest model $(2.40 \mathrm{~mm} ; 1.00 \mathrm{~mm} ; 0.60 \mathrm{~mm} ; 0.30 \mathrm{~mm} ; 0.15 \mathrm{~mm}$ and $0.075 \mathrm{~mm}$ ). The identification of the mineral phases was analysed by the XRD technique (X-ray diffraction) in a Shimadzu diffractometer model XRD 6000, using $\mathrm{Cu} \kappa \alpha$ radiation working at $1.2 \mathrm{~kW}(40 \mathrm{kV}$ e $30 \mathrm{~mA})$. Data were recorded in the $5-60^{\circ} 2 \theta$ range (step size equal to $1 \% \mathrm{~min}$ )

Major and trace elements were analysed by Energy Dispersive X-ray Fluorescence (EDXRF) with a Bruker spectrometer S2 Ranger LE equipped with an X-ray tube of $50 \mathrm{~W}(50 \mathrm{kV}, 2 \mathrm{~mA})$, anode of Pd, XFlash ${ }^{\circledR}$ Silicon Drift Detector with resolution $<135 \mathrm{eV}$ for $\mathrm{Mn} \mathrm{K} \alpha$ and 100,000 cps, with cooling system type Peltier (without need for liquid nitrogen) and tool changer primary filters with 9 positions available.

The behaviour of TS was evaluated on the basis of water absorption (WA), apparent specific mass (ASM) and apparent porosity (AP), according to the Archimedes method. The specimens were dried at a temperature of $110^{\circ} \mathrm{C}$ for $24 \mathrm{~h}$ after immersion in a container of water during $24 \mathrm{~h}$. The TS were weighed dried (dry mass), wet (wet mass) and immersed (mass immersed) using an analytical balance. According to the following equations:

$W A(\%)=\frac{\left(m_{w}-m_{d}\right)}{m_{d}} \times 100$

$A P(\%)=\frac{\left(m_{w}-m_{d}\right)}{\left(m_{w}-m_{i}\right)} \times 100$

$\operatorname{ASM}(\mathrm{g} / \mathrm{cm} 3)=\frac{m_{d}}{\left(m_{w}-m_{i}\right)}$

where $m_{w}$ is the wet mass, $m_{d}$ is the dry mass and $m_{i}$ is the mass immersed in water Compressive strength $(\sigma)$ was measured using an EMIC apparatus, model DL-2000 on ten test specimens for the three series of TS, with a cell for small test specimen compression.

$\sigma=\frac{F}{S}$

where $\mathrm{F}$ is the applied force (Kgf) on the test specimen and $\mathrm{S}$ is the cross section area $\left(\mathrm{cm}^{2}\right)$.

\section{Results and discussion}

\subsection{Materials characterization}

CDW elemental composition, shown in Table 2, indicates that this waste is mainly composed of $\mathrm{Si}\left(71.74 \mathrm{wt} . \%\right.$ as $\left.\mathrm{SiO}_{2}\right), \mathrm{Al}$ (14.17 wt.\% as $\mathrm{Al}_{2} \mathrm{O}_{3}$ ) and $\mathrm{Fe}\left(12.11\right.$ wt.\% as $\mathrm{Fe}_{2} \mathrm{O}_{3}$ ). These results are similar to those reported in other previous studies [29-33]. It is also observed a high concentration in other elements as $\mathrm{Mg}$ (3.67 wt.\% of $\mathrm{MgO}$ ), $\mathrm{Ca}$ (3.44 wt.\% of $\mathrm{CaO}$ ), $\mathrm{Na}\left(2.86 \mathrm{wt} . \%\right.$ of $\mathrm{Na}_{2} \mathrm{O}$ ) and $\mathrm{K}\left(2.68 \mathrm{wt} . \%\right.$ of $\left.\mathrm{K}_{2} \mathrm{O}\right)$ according to the mineralogical composition. The trace elements are present at concentrations below 
Table 2

Average concentrations $(n=10)$ of major elements (wt.\%) and trace elements $\left(\mathrm{mg} \mathrm{kg}^{-1}\right)$. Major and trace elements measured by EDXRF.

\begin{tabular}{|c|c|c|c|c|c|c|c|c|c|c|c|}
\hline & $\mathrm{Na}_{2} \mathrm{O}$ & $\mathrm{MgO}$ & $\mathrm{Al}_{2} \mathrm{O}_{3}$ & $\mathrm{SiO}_{2}$ & $\mathrm{P}_{2} \mathrm{O}_{5}$ & $\mathrm{SO}_{3}$ & $\mathrm{~K}_{2} \mathrm{O}$ & $\mathrm{CaO}$ & $\mathrm{TiO}_{2}$ & $\mathrm{Mn}_{2} \mathrm{O}_{3}$ & $\mathrm{Fe}_{2} \mathrm{O}_{3}$ \\
\hline \multicolumn{12}{|c|}{ Major elements } \\
\hline CDW & 0.38 & 1.68 & 9.76 & 75.53 & 0.04 & 0.17 & 0.99 & 6.10 & 1.11 & 0.05 & 4.18 \\
\hline \multirow[t]{2}{*}{ Soil ${ }^{\text {a }}$} & 2.86 & 3.67 & 14.17 & 61.74 & 0.16 & 0.14 & 2.68 & 3.44 & 0.67 & 0.21 & 12.11 \\
\hline & $\mathrm{Ba}$ & $\mathrm{Zr}$ & V & $\mathrm{Cr}$ & $\mathrm{Y}$ & $\mathrm{Rb}$ & $\mathrm{Zn}$ & $\mathrm{Cu}$ & $\mathrm{Sr}$ & $\mathrm{Pb}$ & As \\
\hline \multicolumn{12}{|c|}{ Trace elements } \\
\hline CDW & 483 & 385 & 81 & 58 & 12 & 32 & 88 & 80 & 177 & 28 & 3.8 \\
\hline Soil ${ }^{a}$ & 584 & 203 & 97 & 92 & 21 & 78 & 67 & 28 & 348 & 17 & 4.8 \\
\hline
\end{tabular}

a Continental crust composition [39].

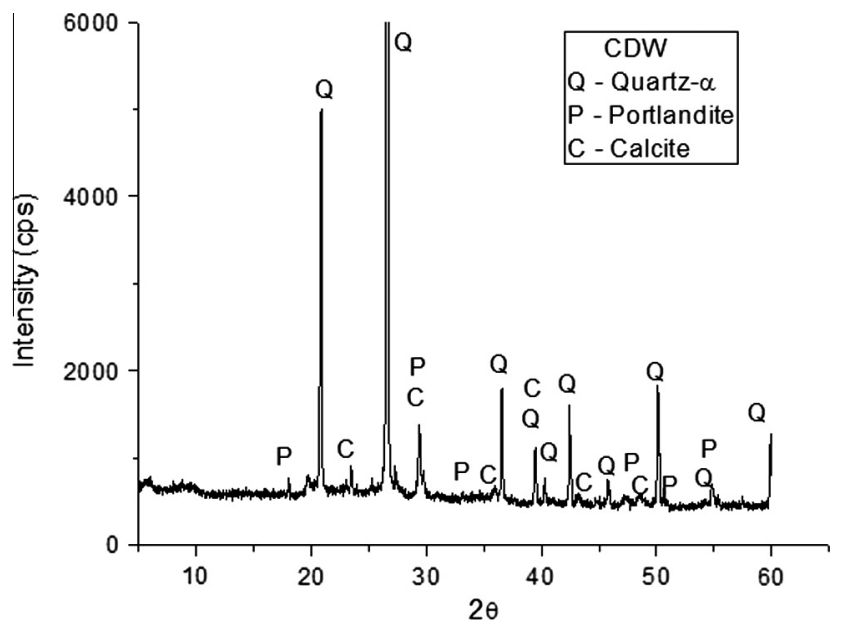

Fig. 1. XRD patterns of CDW.

$0.1 \%$. The main trace elements identified in the CDW were $\mathrm{Ba}, \mathrm{Zr}$, $\mathrm{Sr}, \mathrm{Zn}, \mathrm{V}, \mathrm{Cu}, \mathrm{Cr}, \mathrm{Rb}, \mathrm{Pb}, \mathrm{Y}$ and $\mathrm{As}$, in order of abundance. Some trace elements ( $\mathrm{Ba}, \mathrm{Sr}, \mathrm{V}, \mathrm{Cr}, \mathrm{Rb}$ and $\mathrm{As}$ ) are present in concentrations smaller than uncontaminated soils, but others, such as $\mathrm{Zr}, \mathrm{Zn}, \mathrm{V}$, $\mathrm{Cu}$ and $\mathrm{Pb}$ are higher [39].

The mineralogical composition of the CDW is complex due to the wide range of crystalline and amorphous phases of its components: concrete (coarse gravel or crushed rocks, sand and cement), mortar (sand, lime and cement) and ceramics (fired clay minerals and sand). The RXD analysis confirmed the presence of quartz $\left(\mathrm{SiO}_{2}\right)$, carbonates as calcite $\left(\mathrm{CaCO}_{3}\right)$, hydroxides (potlandite, $\mathrm{Ca}$ $(\mathrm{OH})_{2}$ ) as major crystalline phases and some not identified low intensity peaks, probably due to silicates (Fig. 1). These phases are usually present in natural constituents (stone and sand) and in the used additives (cement and lime). These results are in accordance with the data obtained in other works $[29,30,40,41]$.

Fig. 2 shows the mineralogical composition of some representative test specimens (TSL1-20 and TSL1-30) determined by XRD. The minerals detected included $\alpha$-quartz (PDF 5-490), calcite and other calcium carbonates (PDF 4-637, $\mathrm{CaCO}_{3}$, PDF 47-1743), portlandite (PDF 76-571, $\mathrm{Ca}(\mathrm{OH})_{2}$ ) and some peaks not identified are probably associated to silicates. As was expected, the intensity of the quartz peaks decrease with the addition of lime because its concentration decreased. This fact is especially remarkable at $20.8^{\circ}(2 \theta)$. The peaks associated to calcite and portlandite increase with lime concentration, shown principally at $29.7^{\circ}(2 \theta)$. Moreover, the secondary peaks of quartz appear to increase due to the coincidence of peaks of other phases with the quartz or with the preferential orientation of quartz.

Furthermore, other phases of carbonates and hydrated calcium silicates are formed during the reaction between CDW and lime or cement mixed with water. These phases as well as the silicates are responsible for increasing the mechanical strength of the material during the curing process. Likewise, carbonates together with organic matter and free iron oxides are other binding agents [4244]. Calcium carbonate occurs as coating over or between particles binding them, closing pores and improving the technological properties of the testing samples (probes). Besides, the raw materials used to produce red ceramics are rich in iron oxides (hematite e goethite) and clay minerals (kaolinite and mica). The red ceramics used in this region are produced from kaolinitic clays fired at temperatures smaller than $900{ }^{\circ} \mathrm{C}$ [ 45$]$. The crystalline structures of the clay minerals are destroyed between 500 and $900{ }^{\circ} \mathrm{C}$ and transformed in metakaolinite and hematite when the material is fired
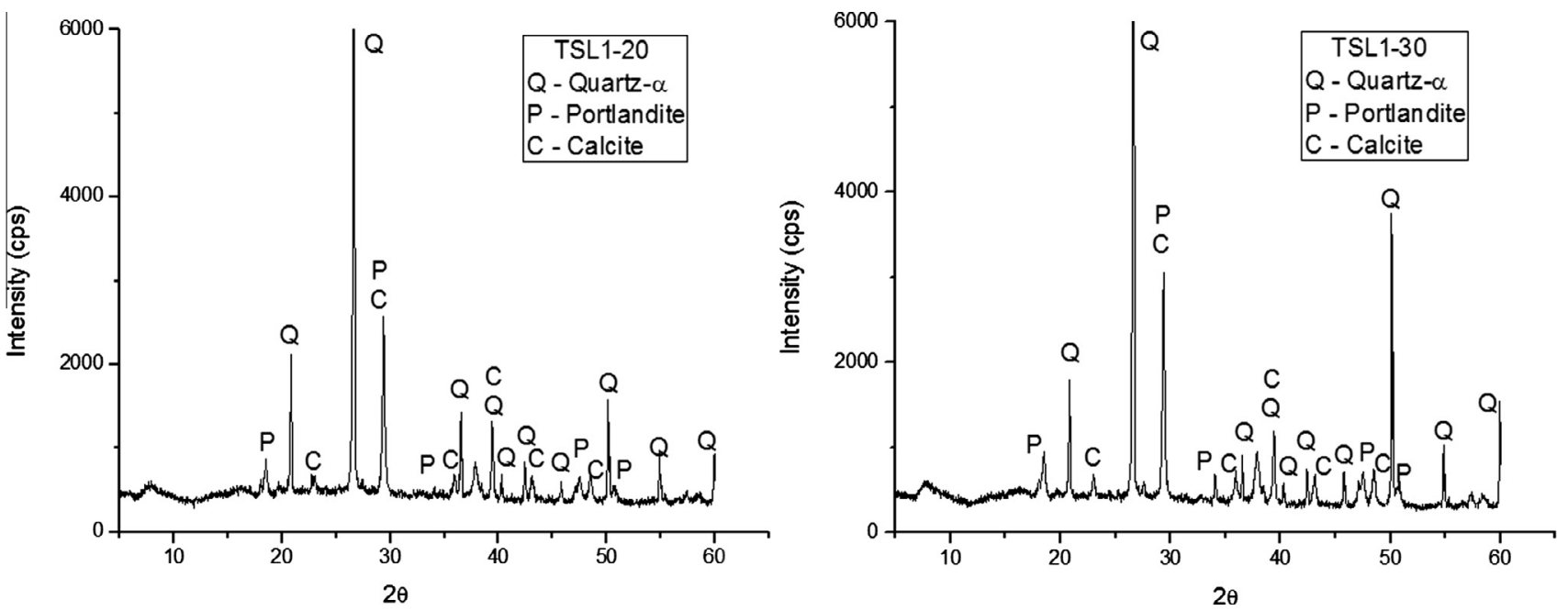

Fig. 2. XRD patterns of TSL1-20 and TSL1-30. 


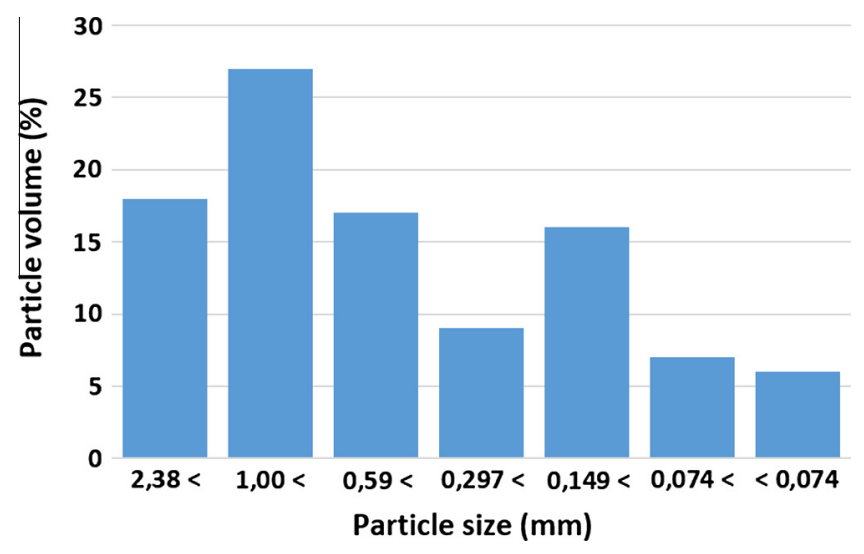

Fig. 3. Granulometric range curve of the CDW.

to produce the bricks $\left(800-900{ }^{\circ} \mathrm{C}\right)$, releasing the amorphous silica and alumina. The reaction of these amorphous phases to mullite phase formation occurs only at temperatures above $900{ }^{\circ} \mathrm{C}$. Thus, after firing there are iron minerals, fine silica and alumina in the powder of crushed red ceramic materials, and a broad class of siliceous and siliceous aluminous materials can be formed, during the cure process. These materials when finely divided (as is the case of nano-metakaolinite) they have pozzolanic activities and have cementitious (binding) properties. Then, the ceramics materials in the CDW have amorphous phases which will contribute to the formation of new phases together with lime or cement and water contributing to improve the physical properties of the TS.

The results of the particle size analysis of CDW are shown in Fig. 3. The granulometric profile of CDW revealed that the sample presented a wide range of particles sizes, with an asymmetric distribution of particles, which can be considered as a sandy material (From 2 to $0.075 \mathrm{~mm}$ ) according to NBR 7225 [46]. Fig. 3 denotes two mainly populations of particles. The first population has a significant particle number of around $149 \mu \mathrm{m}$ of diameter. The intermediate fraction is the greatest fraction in this sample; most of the particle distribution in CDW was retained above $1 \mathrm{~mm}$. The mixture of particles with different sizes improves the packing of the particles, decreasing the porosity and water absorption and increasing the TS density.

\subsection{Technological properties}

The results shown in Table 3 indicate that the apparent porosity decreases with the addition of $20 \%$ of cement and increases with the higher cement concentration (30\%). TSL has a similar behaviour, the addition of lime up to $25 \%$ decreases the apparent

Table 3

Technological properties for each composition (after 28 days cure).

\begin{tabular}{lllll}
\hline & $\begin{array}{l}\text { Water } \\
\text { Absorption } \\
\text { WA (wt.\%) }\end{array}$ & $\begin{array}{l}\text { Apparent } \\
\text { Porosity AP } \\
(\%)\end{array}$ & $\begin{array}{l}\text { Apparent Specific } \\
\text { Mass ASM } \\
\left(\mathrm{g} \mathrm{cm}^{-3}\right)\end{array}$ & $\begin{array}{l}\text { Compression } \\
\text { Strength } \sigma \\
(\mathrm{MPa})\end{array}$ \\
\hline TSC1-10 & 18.51 & 32.09 & 1.72 & 4.12 \\
TSC1-20 & 18.06 & 31.62 & 1.75 & 7.39 \\
TSC1-30 & 19.09 & 32.11 & 1.80 & No fracture \\
TSC2-10 & 18.57 & 32.06 & 1.71 & 4.26 \\
TSC2-20 & 18.21 & 31.94 & 1.80 & 7.73 \\
TSC2-30 & 19.24 & 32.97 & 1.84 & No fracture \\
TSL1-20 & 14.45 & 27.31 & 1.82 & 5.31 \\
TSL1-25 & 13.60 & 26.03 & 1.81 & 5.35 \\
TSL1-30 & 14.35 & 27.27 & 1.81 & 5.65 \\
TSL1-35 & 14.26 & 28.37 & 1.85 & 5.57
\end{tabular}

The values of all mechanical properties were obtained as an average of $10 \mathrm{TS}$ measurements. porosity and increases with higher lime content (30 and 35\%). This physical property is very important, because it is related to the water absorption of the TS $[47,48]$. Therefore the water absorption also follows this same trend because both properties are directly related, although water absorption is related mostly to open porosity. According to the Brazilian standards [49], the average WA of ceramic components should be at most $22 \%$, for ceramic blocks or at most $18 \%$ for roof tiles. Our results in Table 3 agree with this regulations for ceramic blocks (TSC1 and TSC2) and for roof tiles (TSL1). Water absorption should not be greater than $20 \%$ by weight according to ASTM C-90 [50] and ASTM C-55 [51] specifications. The maximum water absorption limit is dependent on the weight classification of the brick (light < WA20\%; medium < WA15\%; normal $<$ WA13\%). The result of the water absorption test presented in Table 3 indicates that all the values are agree with the maximum permissible value of $20 \%$. Moreover, the UNE 41170 [52] establishes the test method to determine the water absorption and the UNE 41166 standard [53] classifies concrete blocks and stablishes the maximum water absorption values: Hllow load-bearing block WA < 29\%; External non-load Bearing WA < 29\%; internal non-load bearing WA $<32 \%$. Table 3 shows that all TS comply with the maximum values established.

The apparent specific mass (ASM) increases with the concentration of cement because its density is higher than CDW and also cement occupy the open pores. On the other hand, with the addition of lime the apparent density presents a wide range of variation.

The compression strength (test to calculate the rupture (collapse) of the test specimens, according to Eq. (4)) increases as the binder (cement or lime) percentage increases (Table 3 ). This result is likely due to the decrease in the volume fraction of interconnecting open pores, which act as large fracture flaws reducing compression strength [54]. Samples composed with $30 \%$ of cement did not fracture because the resistance acquired by these TS exceeded the maximum capacity of the load cell utilized (2000 kgf). In relation to the type of fracture obtained in TS after the compression resistance, these shown a prismatic fracture, which is characteristic of TS that are exposed to a homogeneous distribution of load during the test (Fig. 4).

According to NBR 7170 [55], for ceramic bricks, the axial resistance of massive sintered bricks is classified in the following way: class A < 2.5 MPa; class B $2.5<4.0 \mathrm{MPa}$; class C > 4.0 MPa. Comparing these data with the values in Table 3 , all probes can be classified as Class C. Furthermore, the compressive strength required for load-bearing and non-load-bearing walls using concrete blocks were 6.86 and $3.43 \mathrm{MPa}$ respectively, in accordance with ASTM C-90 [50]. Moreover, the UNE 41166 standard [53] that classifies concrete blocks, designates and establishes the requirements, as well as, the complementing 41167 and 41172 UNE standards [56,57], establish the following values in each type of block: Hllow load-bearing block > $6 \mathrm{MPa}$; External non-load Bearing > $4 \mathrm{MPa}$; internal non-load bearing $>2.5 \mathrm{MPa}$.

It was observed that the mean values of simple compression strength in TSC with 28 days of curing were very different for the mixtures TSC-10 and TSC-20, showing resistance around 4 and $8 \mathrm{MPa}$, respectively. According to TSL1 compression strength results, shown similar mean values for the different mixtures, between 5.31 and $5.65 \mathrm{MPa}$, obtained the best result in sample TSL1-30. Since there are no particular specifications for bricks with waste added, the results obtained were compared with the limit values for soil-cement bricks and ceramic bricks. The NBR-8491 guidelines [58] state that the mean resistance of soil-cement bricks should be equal to or over $2.0 \mathrm{MPa}$ and that the individual values of the pieces tested cannot be less than 1.7 MPa. Besides, the obtained values were all over the lower limit of $4 \mathrm{MPa}$ for Class $\mathrm{C}$ massive ceramic bricks for masonry [55]. Additionally, according to the 

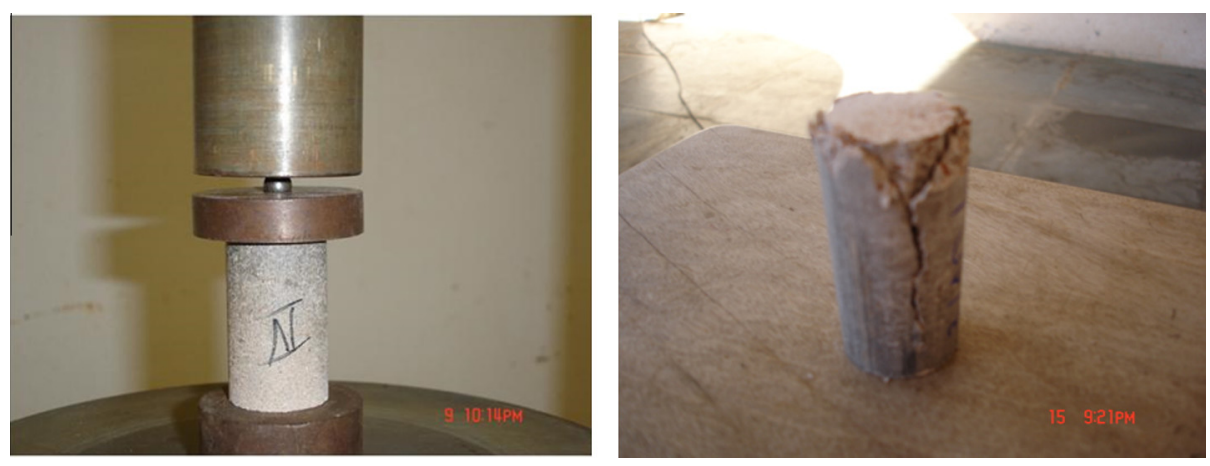

Fig. 4. Image of the TS before (left) and after compression test exhibiting prismatic fracture (right).

ASTM C-90 and the UNE 41166 standards [50,53], the compressive strength required for load-bearing are 6.86 and $6 \mathrm{MPa}$, respectively and in case of non-load-bearing walls using concrete blocks are 3.43 and $4 \mathrm{MPa}$, respectively. The obtained values were all over the both limits stablished for non-load-bearing walls. In case of TSC-20 and TSC-30, the values obtained was over the lower limit required for load-bearing.

On the other hand, the values obtained in the different composition of TSC1 and TSC2 were very similar, indicating that the mixture of 50:20:30 (TSC1) for waste is a good approximation in term of mechanical behaviour of TSC2 prepared with CDW obtained randomly in a recycling plant. Despite the heterogeneity of CDW depending on its origin, the products have reached very similar technological properties. Consequently, it was proved that this heterogeneity is not a limiting factor, when CDW is formed majority by ceramic, concrete and mortar.

When compared both limit values, water absorption and compression strength, according to Brazilian standards for ceramic block for masonry (WA $\leqslant 25 \%$ and $\sigma \geqslant 2.5 \mathrm{MPa}$ ) [59], and the apparent density, for ceramic massive bricks (ASM $>1.7 \mathrm{~g} \mathrm{~cm}^{3}$ ), the results are outstanding, all of the values obtained were within the limits. Mechanical resistance to compression was also very good, where all the probes showed values of resistance to simple compression greater than 4.12 and $5.31 \mathrm{MPa}$ in TSC and TSL respectively, both cases can be classified as class $C$ block (limit value $\sigma>4 \mathrm{MPa}$ ) [30]. All of the values obtained were within the limits stablished in the UNE 41166 standard (WA $\leqslant 29 \%$ and $\sigma \geqslant 2.5 \mathrm{MPa}$ ) [53] and the ASTM C-90 standards (WA $\leqslant 20 \%$ and $\sigma \geqslant 3.43 \mathrm{MPa}$ ) [50]. Another option for the construction of lowcost housing, employed in Brazil since 1948, is the one that uses soil-cement [30]. It is widely used in rural areas and in poorer regions due to the technical and economic advantages that the material offers. The Brazilian standards established for soilcement bricks dictate the following mean limit values: resistance strength $\geqslant 2.0 \mathrm{MPa}$ and water absorption $\leqslant 20 \%$, after seven days curing $[41,60]$. Therefore, the values obtained for the TS manufactured with construction and demolition waste and binder additives (cement or lime) are also better than the limit values established for soil-cement bricks.

The predominance of silicates and carbonates, the presence of minerals originating also from burning at low temperature (in general $<900{ }^{\circ} \mathrm{C}$ ) of clays in the structural ceramics and the high concentration of the fine granulometric fraction, favours the lime and cement reaction, which increases the $\mathrm{pH}$ of the material, with the residue forming cementing agents (calcium carbonates and silicates) and improving the physical properties of the TS [61]. Therefore, the use of CDW with lime or cement for the production of bricks with appropriate physical properties is a good option for the use of both the fine fractions present in these residues and the more roughly ground fraction.

\subsection{Economic and environmental implications}

The best result was exhibited by composition TSC-30; however, from an economic point of view, perhaps it would be possible to choose compositions TSC-10 or TSC-20 and TSL1-20 and TSL1-25 to produce bricks. This consideration is founded on the small difference in strength between the samples and, particularly when compared with the requirements of the limits values. In a economic view, lime as binder can be obtained from some of the nearby industries that produce lime as waste, thus avoiding the costs produced by the use of cement.

On the other hand, CDW is generated in all the cities and therefore it is available in all places where take place construction and demolition works. Consequently, the cost of transporting will be even lower than those produced by the use of natural aggregates, since these are extracted in quarries that are usually located away from the cities. Besides, the use of this residue as substitute of natural aggregates would reduce the cost of purchase raw materials.

Additionally, countries as Brazil which present shortages of natural aggregates, using this waste represents savings cost due to the price of raw material and a solution to this problem of availability. In addition to the environmental benefits in reducing the demand on land for disposing the waste, the recycling of CDW can also help to conserve natural resources and to reduce the cost of waste treatment prior to disposal. Moreover, reducing the polluted areas likewise reduce the spread of disease vectors animals (such as flies, cockroaches, scorpions, rats etc.) attracted by the garbage disposed with the CDW. Another economical result of this action, the city administration will save money spent on cleaning areas with CDW disposed and in health care, with treatment of the affected population.

\section{Conclusions}

(a) The present experimental work confirms the possibility of using residues from civil construction (CDW) and binding agents (cement and lime) as raw materials in the manufacture of new construction material as low-cost bricks for masonry walls. Especially, the samples TSC2-20/30 and TSL1-30/70 present the best technological properties. Moreover, the highest values were obtained with cement as binder.

(b) According to the technological properties, all the proposed compositions show higher compressive strength values than Brazilian, European and American standards. The main values were 5.47 and 7.61 MPa adding lime and cement respectively. These both are in accordance with the requirements for NBR 7170 in the C Category (minimal compression strength of $4 \mathrm{MPa}$ ). ASTM C-90 and the UNE 41166 standards, 
the compressive strength required for load-bearing are 6.86 and $6 \mathrm{MPa}$, respectively and in case of non-load-bearing walls using concrete blocks are 3.43 and $4 \mathrm{MPa}$, respectively. The obtained values were all over the both limits stablished for non-load-bearing walls. In case of TSC-20 and TSC-30, the values obtained was over the lower limit required for loadbearing.

(c) The fraction of CDW with a particle size below $4.8 \mathrm{~mm}$, which is used in this research work and generally rejected in most of the recycling plants, was confirmed as possible substitute of natural aggregated.

(d) The initial hydration become lime $(\mathrm{CaO})$ predominantly into portlandite $\left(\mathrm{Ca}(\mathrm{OH})_{2}\right)$ and calcite $\left(\mathrm{CaCO}_{3}\right)$ according to XRD analyses. These new minerals together with some hydrated silicates may explain the improving in mechanical resistance.

(e) The typical used CDW composition (50\% ceramic, $20 \%$ concrete and $30 \%$ mortar), is a good proportion as raw material to produce bricks with better mechanical properties that are established by standards.

(f) Similar values of compression resistance in TSC prepared with different samples of CDW (TS1 and TS2), show that the composition of the CDW influences little the mechanical resistance of the TS. This result assures, in principle, that the method can be employed in different recycling units, since it guarantees that the material used is only the mineral fraction contained in civil construction and demolition waste. Furthermore, the present work has shown that construction and demolition waste from different places, with a differentiated composition between them depending on its origin, have achieved the standards according to the technological properties.

(g) In a realistic and economical approximation the use of industrial waste as raw materials would reduce the price of civil construction. A sustainable and environmentally procedure directed to manage the CDW will withdraw the huge volume of this waste discarded in the environment or in landfills and will result in a number of important social and environmental impacts: built low-cost houses; to reduce the raw materials utilization increasing the lifetime of the existing mineral deposits; increase the lifetime of the landfill; protect areas of environmental preservation in the cities neighbourhood; reduce the spread of disease vectors animals (such as flies, cockroaches, scorpions, rats etc.) attracted by the garbage disposed with the CDW in the periphery of cities where the poorest people live. As a result of this action, the city administration will save money spent on cleaning areas with CDW disposed and in health care, with treatment of the affected population.

\section{Acknowledgement}

The authors thank the FAPESP and PIBIC/CNPq and UNESP/ PROPE for the assistance and scientific scholarship awarded to the Brazilian undergraduate students, which participated of this project. PhD student M. Contreras would like to expresses his gratitude for the research contract granted him through The Fellowship Training Program of the University Teaching Staff; reference AP2010-2746, financed by the Spanish Ministry of Education, Culture and Sport (MECD). This is a publication from the CEIMAR Publication Series.

\section{References}

[1] S.C. Ângulo, V.M. John, A.P. Chaves, S.L.M. Almeida, F.M.R.S. Lima, P.C. Gomes, Aperfeiçoamento da reciclagem da fração mineral dos resíduos de construção e demolição: Uso em concretos. In Seminário: O uso da fração fina da britagem (II SUFFIB), São Paulo, Brazil, 2005, pp. 1-6.

[2] S.C. Ângulo, C. Ulsen, P.M. Carrijo, R.M. Silva, V.M. John, H. Kahn, Characterization of Brazilian construction demolition waste coarse recycled aggregate, in: International RILEM Conference on the use of recycled materials in building and structures (RILEM2004), Barcelona, www.reciclagem.pcc.usp. br, viewed on June 24, 2007, at 10:00 UT.

[3] V.M. John, S.C. Ângulo, L.F.R. Miranda, V. Agopyan, F. Vasconcellos, Strategies for innovation in construction demolition waste management in Brazil, in: CIB World building congress, Toronto, www.cib2004.ca, viewed on June 24, 2007, at 10:35 UT.

[4] C. Ulsen, H. Kahn, S.C. Angulo, V.M. John, Applied mineralogy characterization of construction and demolition waste from Brazilian recycling plants, 8th International Congress of Applied Mineralogy (8th ICAM), Águas de Lindóia, Brazil, 2004.

[5] A. Coelho, J. de Brito, Economic viability analysis of a construction and demolition waste plant in Portugal - Part I: location, materials, technology and economic analysis, J. Cleaner Prod. 39 (1) (2013) 338-352.

[6] A. Coelho, J. de Brito, Economic viability analysis of a construction and demolition waste plant in Portugal - Part II: economic sensitivity analysis, J. Cleaner Prod. 39 (1) (2013) 329-337.

[7] A. Coelho, J. de Brito, Environmental analysis of a construction and demolition waste plant in Portugal - Part I: energy consumption and $\mathrm{CO}_{2}$ emissions, Waste Manage. 33 (5) (2013) 1258-1267.

[8] A. Coelho, J. de Brito, Environmental analysis of a construction and demolition waste plant in Portugal - Part II: environmental sensitivity analysis, Waste Manage. 33 (1) (2013) 147-161.

[9] J. Wartman, D.G. Grubb, A.S.M. Nasim, Select engineering characteristics of crushed glass, J. Mater. Civ. Eng. 16 (6) (2004) 526-539.

[10] C.S. Poon, D. Chan, Feasible use of recycled concrete aggregates and crushed clay brick as unbound road sub-base, Constr. Build. Mater. 20 (2006) 578-585.

[11] A. Arulrajah, M. Ali, M. Disfani, S. Horpibulsuk, Recycled-glass blends in pavement base/subbase applications: laboratory and field evaluation, J. Mater. Civ. Eng. 26 (7) (2014) 04014025.

[12] R. Taha, A. Al-Harthy, K. Al-Shamsi, M. Al-Zubeidi, Cement stabilization of reclaimed asphalt pavement aggregate for road bases and subbases, J. Mater. Civ. Eng. ASCE 14 (3) (2002) 239-245.

[13] L.R. Hoyos, A.J. Puppala, C.A. Ordonez, Characterization of cement fiber-treated reclaimed asphalt pavement aggregates: preliminary investigation, J. Mater. Civ. Eng. ASCE 23 (7) (2011) 977-989.

[14] A. Arulrajah, J. Piratheepan, M. Disfani, Reclaimed asphalt pavement and recycled concrete aggregate blends in pavement subbases: laboratory and field evaluation, J. Mater. Civ. Eng. 26 (2) (2014) 349-357.

[15] A. Arulrajah, M.M.Y. Ali, M.M. Disfani, J. Piratheepan, M.W. Bo, Geotechnical performance of recycled glass-waste rock blends in footpath bases, J. Mater. Civ. Eng. 25 (5) (2013) 653-661.

[16] M.A. Rahman, M. Imteaz, A. Arulrajah, M.M. Disfani, Suitability of recycled construction and demolition aggregates as alternative pipe backfilling materials, J. Cleaner Prod. 66 (2014) 75-84.

[17] A. Rao, K.N. Jha, S. Misra, Use of aggregates from recycled construction and demolition waste in concrete, Resour. Conserv. Recycl. 50 (1) (2007) 71-81.

[18] R.V. Silva, J. De Brito, R.K. Dhir, Properties and composition of recycled aggregates from construction and demolition waste suitable for concrete production, Constr. Build. Mater. 65 (2014) 201-217.

[19] M. Martín-Morales, M. Zamorano, A. Ruiz-Moyano, I. Valverde-Espinosa, Characterization of recycled aggregates construction and demolition waste for concrete production following the Spanish Structural Concrete Code EHE08, Constr. Build. Mater. 25 (2) (2011) 742-748.

[20] J. Yang, Q. Du, Y. Bao, Concrete with recycled concrete aggregate and crushed clay bricks, Constr. Build. Mater. 25 (4) (2011) 1935-1945.

[21] C.S. Poon, S.C. Kou, L. Lam, Use of recycled aggregates in molded concrete bricks and blocks, Constr. Build. Mater. 16 (5) (2002) 281-289.

[22] S. Neves-Monteiro, C.M. Fontes-Vieira, On the production of fired clay bricks from waste materials: a critical update, Constr. Build. Mater. 68 (2014) 599610.

[23] M.M. Sabai, M.G.D.M. Cox, R.R. Mato, E.L.C. Egmond, J.J.N. Lichtenberg, Concrete block production from construction and demolition waste in Tanzania, Constr. Build. Mater. 79 (2013) 9-19.

[24] C. Leiva, J. Solís-Guzmán, M. Marrero, Arenas.C. García, Recycled blocks with improved sound and fire insulation containing construction and demolition waste, Waste Manage. 33 (2013) 663-671.

[25] M.N. Soutsos, K. Tang, S.G. Millard, Concrete building blocks made with recycled demolition aggregate, Constr. Build. Mater. 25 (2011) $726-735$.

[26] V.A. Mymrin, K.P. Alekseev, R.E. Catai, R.L.S. Izzo, J.L. Rose, A. Nagalli, C.A. Romano, Construction material from construction and demolition debris and lime production wastes, Constr. Build. Mater. 79 (2015) 207-213.

[27] S.E. Zordan, Entulho da indústria da construção civil, www.reciclagem.pccc. usp.br, viewed on June 01, 2007, at 09:00 UT.

[28] CONAMA - Conselho Nacional do Meio Ambiente, Resolução $N^{\circ} 307$, de 5 de julho de 2002, http://www.mma.gov.br/port/conama/legiabre.cfm?codlegi= 307.

[29] S.R. Teixeira, L.C.N. Lima, M.C. Lucas, Recycling of civil engineering solid waste to produce modular bricks, in: 2nd International Congress University-Industry Cooperation, 2007, Perugia, Itália. 
[30] M. Contreras, M.J. Gázquez, I. García-Díaz, F.J. Alguacil, F.A. López, J.P. Bolívar, Valorization of ilmenite mud waste for the manufacturing of sulfur polymer cements, J. Environ. Manage. 128 (2013) 625-630.

[31] P. Saiz-Martínez, M. González-Cortina, F. Fernández-Martínez, A. RodríguezSánchez, Comparative study of three types of fine recycled aggregates from construction and demolition waste (cdw), and their use in masonry mortar fabrication, J. Cleaner Prod. (2016) (in press).

[32] A.E.B. Cabral, Concrete with construction and demolition wastes (CDW), EcoEfficient Concr. (2013) 340-367.

[33] A. Coelho, J. De Brito, Conventional demolition versus deconstruction techniques in managing construction and demolition waste (CDW), in: Handbook of Recycled Concrete and Demolition Waste, 2013, pp. 141-185.

[34] NBR 5732, Portland Cement - Specification, Brazilian Association of Technical Standards, 1991.

[35] NBR NM-10, Portland Cement - Chemical Analysis - General Procedures, Brazilian Association of Technical Standards, 2012.

[36] NBR 260-110, Standard Reference Materials: Portland Cement Chemical Composition Standards, Brazilian Association of Technical Standards, 1988.

[37] NBR 7175, Hydrated Lime for Mortars - Requirements, Brazilian Association of Technical Standards, 2003.

[38] NBR 6453, Quick Lime for Civil Construction - Requirements to Quick Lime of Civil Construction - Requirements, Brazilian Association of Technical Standards, 2003.

[39] M. Contreras, R. Pérez-López, M.J. Gázquez, V. Morales-Flórez, A. Santos, L. Esquivias, J.P. Bolivar, Fractionation and fluxes of metals and radionuclides during the recycling process of phosphogypsum wastes applied to mineral $\mathrm{CO}_{2}$ sequestration, Waste Manage. 45 (2015) 412-419.

[40] R.R. Menezes, H.S. Ferreira, G.A. Neves, H.C. Ferreira, The use of granite wastes as ceramic raw materials (in Portuguese), Cerâmica 48 (306) (2002) 92-101.

[41] P.E.M. Silveira, C.A. Nóbrega, Construction and demolition waste use in soilcement (in Portuguese), HOLOS Environ. 5 (2) (2005) 152-168.

[42] J.B. Dixon, S.B. Weed, Minerals in Soil Environments, second ed., Soil Science Soc Amer Spec Publ. 1, SSSA, Madison, Wi, 1989. 1244p.

[43] C. He, B. Osbaeck, E. Makovicky, Pozzolanic reactions of six principal clay minerals: activation, reactivity assessments and technological effects, Cem. Concr. Res. 25 (8) (1995) 1691-1702.

[44] S.A. Abo-El-Enein, M.S. Amin, F.I. El-Hosiny, S. Hanafi, T.M. ElSokkary, M.M. Hazem, Pozzolanic and hydraulic activity of nano-metakaolin, HBRC J. 10 (1) (2014) 64-72.

[45] S.R. Teixeira, S.A. de Souza, C.A.I. Moura, Mineralogical characterization of clays used in the structural ceramic industry in west of S. Paulo State, Brazil, Cerâmica 47 (304) (2001).
[46] NBR 7225, Stone Materials and Natural Aggregates, Brazilian Association of Technical Standards, 1993.

[47] M. Contreras, M.I. Martín, M.J. Gázquez, M. Romero, J.P. Bolívar, Valorisation of ilmenite mud waste in the manufacture of commercial ceramic, Constr. Build. Mater. 72 (2014) 31-40.

[48] M. Raigón-Pichardo, G. García-Ramos, P.J. Sánchez-Soto, Characterization of a waste washing solid product of mining granitic tin-bearing sands and its application as ceramic raw material, Resour. Conserv. Recycl. 17 (2) (1996 109-124.

[49] NBR 15.270-2, Ceramic Components Part 2: Structural Ceramic Block, Perforated Block, Load-Bearing Masonry - Terminology and Requirements, Brazilian Association of Technical Standards, 2005.

[50] ASTM C90, Standard Specification for Loadbearing Concrete Masonry Units, American Society of Testing Materials, 2015.

[51] ASTM C55, Standard Specification for Concrete Building Brick, American Society of Testing Materials, 2014.

[52] AENOR, Spanish Association for Standardisation and Certification, UNE 41170 Concrete blocks, Water absortion, 1989.

[53] AENOR, UNE 41166: Concrete Units, Definitions, Classification and General Characteristics, Spanish Association for Standardisation and Certification, 2000.

[54] M. Contreras, M.I. Martín, M.J. Gázquez, M. Romero, J.P. Bolívar, Manufacture of ceramic bodies by using a mud waste from the $\mathrm{TiO}_{2}$ pigment industry, Key Eng. Mater. 663 (2016) 75-85.

[55] NBR 7170, Ceramic Solid Brick for Masonry - Specification, Brazilian Association of Technical Standards, 1983.

[56] AENOR, UNE 41167: Concrete Blocks. Dimensions Measure and Shape Checking, Spanish Association for Standardisation and Certification, 1989

[57] AENOR, UNE 41172: Concrete Blocks. Determination of the Compressive Strength, Spanish Association for Standardisation and Certification, 1989.

[58] NBR 8491, Brick Soil - Cement - Requirements, Brazilian Association of Technical Standards, 2012.

[59] NBR 7171, Ceramic Block for Masonry - Specification, Brazilian Association of Technical Standards, 1995.

[60] M.M. Rolim, W.J. Freire, A.L. Beraldo, Comparative strength analysis of specimens, bricks, and panel molded by soil-cement (in Portuguese), Revista Brasileira de Engenharia Agrícola e Ambiental 3 (1) (1999) 89-92.

[61] S.R. Teixeira, Caracterização de argilas usadas para produção de cerâmica vermelha e estudo das alterações nas suas propriedades pela adição de resíduos sólidos. Tese de Livre-docência, Faculdade de Ciências e Tecnologia FCT, Universidade Estadual Paulista Júlio de Mesquita Filho - UNESP, Campus de Presidente Prudente - SP, Brasil, outubro de 2006 